\title{
Fataawa Al-Masjid Al-Aqsa on a Visa From Occupier (Critical Study)
}

\author{
D. Mohammed Hassan Alloush* \\ Assistant Professor of Jurisprudence and Fundamentals Al-Aqsa Community College - Al-Aqsa University \\ *Corresponding Author: D. Mohammed Hassan Alloush, Assistant Professor of Jurisprudence and \\ Fundamentals Al-Aqsa Community College - Al-Aqsa University
}

\begin{abstract}
Al-Aqsa Mosque has a great place among Muslims. It is the first of the Qiblatain the two mojes, the masri of the Messenger of Allah e, is located at this time under The Zionist occupation, God decipher his family. The issue of his visit was raised on a visa from the Zionist occupier, Some of the leading scientists visited him. This study aims to demonstrate the legitimate judgment in the visit Al-Aqsa Mosque on a visa from the occupier. To this end, the researcher has followed the curriculum inductive by extrapolating the opinions of scientists and their opinions issued on the subject, then Critical analytical approach by analyzing these opinions, criticing them and indicating the most likely ones. It has the study concluded a number of findings, the most important of which is that visiting Al-Aqsa Mosque is mustahabb. Normalization with the enemy is haraam, saying that visiting Al-Aqsa Mosque on a visa from the occupier It is haraam, more likely than others.
\end{abstract}

\section{INTRODUCTION}

Praise be to Allah, Lord of the Worlds, peace and blessings be upon the most honored prophets and messengers His deity and whoever followed his gift to the day of judgment. After:

The Islamic law would have made the Al-Aqsa Mosque a great place, and linked Between him and the Grand Mosque in linking my doctrines to the holy shrines of Muslims each other, he said, andexalted:) Suhaan, who was captured by his slave at night, from the sanctuary of the sanctuary to the most stringent mosque, which We blessed about him to show him from our signs that he is the sighteous (. (Al-Israa: 1). He has wished The Prophet e visits him in many conversations one of them: "The Travellors shall be screwed only to the 3 mosques of this mosque. And the mosque of the haram and the mosque of the al-Qas"' [1]. This makes the hearts of Muslims pity for this mosque and wish prayer in it before death. But it's in this time. Falls under the Zionist occupation and no one can visit it without a visa from the occupier the usurper, which made the scholars disagree in the ruling of his visit in such a situation. From the study of this topic is a critical and impartial study of political whims and affiliations, with the aim of Reach the most correct opinion in the matter.

\subsection{Importance of the Topic}

The importance of this topic is demonstrated by the following points:

1. It's of contemporary topics that affect the life of the nation and need to be identified.

2. It's Of the topics raised around him is a sensation among Muslims Opt stand on them.

3. The obligation to work on consolidating the word of Muslims and their distance from disagreement.

\subsection{Reasons for Choosing Topic}

The reasons for choosing a topic are the following

1. No doubt. That the importance of the topic is one of the reasons for choosing it.

2. Statement of the Shari'a judgment in the subject is to distance Muslims from falling into the forbidden. 


\subsection{Research Plan}

The research plan included

On: Introduction, Three Investigations, Conclusion, as follows:

The first consideration: The truth of the fatwa and its rightful judgment

The Second Examination: The Virtues of Al-Aqsa Mosque in the Book and Sunnah

Third: Fataawa al-Masjid al-Aqsa Fataawa

Then the conclusion, which includes the most important findings and recommendations reached by the researcher.

The first study: The truth of the fatwa and its rightful judgment

To find out the truth of the fatwa, it is necessary to explain the meaning of that word in the Arabic language,

In the terminology of fuqaha', and the statement of the terms related to fatwa, such as: Ijtihad and Judiciary, then

The statement of the advisory judgment of the fatwa, and therefore, the nature of the research required that this consideration be in

Two requirements are as follows:

\section{The first requirement: The truth of fatwa is a language and idiom}

\section{First: Fatwa as a language}

Fatwa from Fatwa, which is the language of the source of the verb (fatwa), and Fatwa taken from (boy),

Which is in the sense of ibana, it is said: Fatah in the matter if his father is to him [1], and the origin of (fatwa) from the boy, which is: the young man strong talk, as if he - Strengthens their scientific statement and power [2].

The son of Persia has gone to bring together those who were concerned with the word Fatwas, namely: the ibana and the fatwa, and he said: "Boy: A faa and a letter who is ill Aslan: one is indicative of tarwah and his grandparents, and the other is indicative of indicating the verdict" [3].

which is clear by looking at the origin of the word fatwa In the language, the fatwa and fatwa are convergent words intended to indicate the problem of The judgments, and the evidence of that is the meaning of the exalted saying:) They will say three of a quorum of them as their own, and they say five, their siblings. They are stunted in the absent, and they say seven and eight of them, "They are their dogs', say, My Lord, I know by their distance that he does not know them, but a little, and thou shalt not pass in them. But there is no one in them ((Al-Kahf: 22), the referendum came in verse meaning the request of the young men to indicate a matter of form. On the people, and no one was able to reach the right thing in it [4], as well as in the saying:

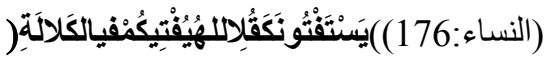

Then he explained that what is meant by the referendum is the statement and clarification, and he said:) Allah shows you to be deceived and Allaah knows everything ((Al-Nisa'176).

And some people went the language indicates that the boys revealed, IbnSayyidah said: "But we spent a thousand fatwas Balyaa: For the abundance of P-T-Y and the lack of P-T-F"

\section{Second: Issuing Fatwas is a term}

Purists saidto give fatwas many definitions, the researcher will mention some of them, and then indicate the chosen one and the reason for his choice. As follows:

1. Imam al-Qarafi defined al-Fatwas as "telling that Allaah is obligatory or permissive" [1].

It is clear that this definition in its face includes Fatwas and the judiciary. Fatwas is telling It is narrated from Allaah, not on the part of obligating, but the judiciary is a telling on the part of the creation and obligatory. 
However, those who follow the sayings of Qarrafi finds that this definition has meant to differentiate between the fatwa and the verdict, and was interested

in thestatement of what they divide, which is that the fatwa telling, and the ruling establish, where it is stated in the book Differences Saying: The fatwa and the ruling are both telling about the ruling of Allaah, but the fatwa is telling about Allaah in compelling or permissiveness, and the ruling means creation and obligatory from Before Allahuta'ala" [2].

2. Imam Bahuti defined al-Ifta' as saying: "It is to identify the legitimate ruling of those who asked him" [1].

\section{The pros of this definition are two things}

First, he's tied up. The statement here is the Shariah ruling, and that the fatwa is originally concerned with the Shariah provisions without other linguistic, legal, mental and other provisions.

As for the second, he said, "To whom he asked," Thus, the statement of judgment comes out in the beginning, it is not called boys, but it is called guidance and instruction [2].

3. Al-Jarjani defined Fatwas as: "An indication of the ruling on the matter" [1].

Two things are taken on this definition:

The first is that it includes the linguistic definition of fatwa. The fatwa was known to be cleared and clarified [2].

(ii) It is taken for him to enter the fatwas in all matters, of which linguistic, mental, legal and other.

4. Sheikh Muhammad Suleiman al-Ashqar defined al-Ifta' as: "News by virtue of Allah Exalted for a legitimate guide to those who asked him in a descending order."

which seems to have surpassed his predecessor in The definition of fatwas is two restrictions, namely:

A. Kun al-Ifta In conjunction with the forensic evidence, and this is a constraint that comes out of the words of the imitation, it is not called a boy, but a tale. For imitated words, not called a mustache, it is a transfereed of imitated boys [1].

b. Customizing the subject of fatwa downlight, which is meant by the downward thing here: is the special fact that occurred to the person asked about its judgment [2].

\section{Selected Definition:}

After reviewing the most important definitions of fundamentalists for issuing fatwas, and the statement of its limitations, the researcher chooses the following definition: Fatwas is: The legitimate one who knows him as a guide to those who asked him."

\section{Reasons for choosing a definition}

The justification for choosing this definition is as follows:

It is known as fatwas by statement, not by news, and this In order to give the reader the illusion that the news includes Fatwas and the judiciary.

To say that the fatwa is the "Shari'ah judgment", Gender in the definition, which includes the statement of the Shariah judgement from whether by writing or teaching, It also includes the statement of the legitimate judgment of those who asked for it

Restricting the legitimate judgment of those who know him by his evidence, comes out a statement The Shari'ah ruling from the commoner for another year, it is not called fatwa, because the commoner does not know Judging by its evidence, and because knowledge of the evidence includes knowledge of its validity and its meaning, this only gets from Jurisdiction.

\section{Third: Words Relevant to Fatwas}

Language: comes in the sense of judgment, collecting counties, Al-Razi said: "He served as a judge: any judgment" [1], and from him the meaning of the exalted saying:) And your Lord ruled only You shall worship Him, except Him, and by the two good, either they shall be known to thee. The elder is one of them or both, and shall not say to them that they will not fall down. And say to them a kind word ((Al-Israa: 23$)$, and 
Thejudiciary comes in other meanings: such as emptiness, performance and termination.

As for the judiciary, it is: "Notification by virtue of Shara in the face of obligatory law" [3], and from the previous definitions the difference between Fatwas and the judiciary can be summarized as follows:

1. That the fatwa is Tell about the legitimate judgment in the matter who is entitled to it, and the judiciary is the establishment of the judgment between the rivors who are worthy of that, too.

2. That the verdict The mufti is not obliged to the mufti or to others, but to take it, and also to leave it. As for the judiciary: the ruling is binding on the parties, and accordingly, if one of the parties is invited to Hearing the fatwa of the mufti, do not answer him, and you answer him if he is called to the judiciary, and he is forced to if he abstained, because the judge was intended to resolve the differences and cut off the rivalries. [4]

3. That the mufti is a fatty Judgment is a religion, meaning that it gives a legitimate judgment as it is at the inside of the matter, while the judge judges For example, if a man says to Mufti, "I told my wife you are divorced, with a view to telling what He went on, and he was lying in that case, in which case the Mufti missed not to divorce. The judge does not look at the intentions, because the word is explicit in the statement of divorce, and it is judged that it takes place [2].

4. That the judge is easier. I mean, and closer to safety than the Mufti, because the Mufti would issue what he attended from saying, As for the judge, he will be vigor and proving, and who is careful to prepare him of the right what is not prepared for others [3].

5. The judge's verdict Partial, it is specific to a particular fact that does not exceed the two disputing parties, while the Mufti Fetti is a total general sentence, so the judge is serving a certain judge over a particular person, Private binding, the Mufti general advisory opinion is not binding [4].

6. The judiciary isn't. Except in an operative word, while the fatwa is a pronunciation and is written and actually [5].

\section{Second: Diligence}

Diligence language: Derived from substance (effort), meaning effort and energy, or open: (effort), meaning endure effort and hardship, diligence in language is:

exerting effort and emptying the capacity to achieve a matter of hard things, whether it is in matters sensory such as walking and working, or in moral matters such as extracting a judgment or a mental theory, or Legitimate, or linguistic. [1]

As for diligence idiomatic: the fundamentalists have cited him Numerous definitions of which are:

1. Imam al-Ghazali knew him after mentioning his linguistic meaning: "But The word became in the knowledge of scholars especially to make a hard effort to seek knowledge of the provisions of the Sharia." [2]

2. Al-Amedi defined him as: "The expansion of the request think of some legitimate provisions in a face that feels self-incapable of more" [3]

3. Others knew it: "The jurist made his power in Deducing judgments of the legitimacy of the evidence considered legitimate". [1]

Thus the researcher finds a clear convergence between these tariffs, however, some fundamentalists added to the definition some limitations increase in clarification, Such as: (Sharia provisions), and whoever did not restrict him with this restriction of them, he considered that the word (Faqih) sings about it.

Some fundamentalists said: "On the face of self-sense inability to do more," in which a signal that it is not enough to just exert power, but must The feeling that he spared no effort to do.

The fundamental difference between Ijtihad and Fatwas is: Ifta' is what is known, of course or thought, while Ijtihad is only in matters. Connivity. [2]

\section{Second requirement: Sharia ruling for issuing Fatwas}

The meaning of the "Almighty" indicates in the women's surah: "He will call you," Allah will break you. (Women: 176), to the importance of the referendum in religion, and the need to take 
care of it for the public and private of the mandate, so the fundamentalists have stated that the fatwa is endured by the commissioning provisions five, namely: obligatory, scarring, permissiveness, haraam, and hates, only that which appears from Their words are that the fatwa has an original ruling, and the other provisions are attached to this original judgment according to relates to it.

Fatwas in terms of The original is an imitation of competencies. Al-Nawawi, may Allah have mercy on him, said in the forefront of the total: Imposing an adequacy, if he is questioned and not in other people, he must answer "[1]. It came from him in the kindergarten, what it says: "When there is only one fit in the place For the fatwa, he had to make a fatwa, and if there were others, he is one of the functions of competencies, yet It is not permissible to hasten to him" [2]. It is the legitimate evidence that indicates that the statement is obligatory and that it is forbidden to keep the knowledge secret for those who He knows him, the meaning of the Almighty: )And when Allaah has taken The covenant of those who have died the Scripture, thou shalt shaltshalt not be shalt. And we took him away after their bare, and they bought him a little price; and he was desperate. They are bred(( $\mathrm{Al}$ Imran: 187), The interpreters said: The verse is reprimand in everyone who muted a flag from the book, who knows something, let him know. If the secret of science is perished, and also it is not permissible for the world to keep silent on his knowledge, nor for the ignorant to keep silent. In his ignorance, and the verse, and if it came in the Jews, when they commanded faith in Muhammad, and the statement of his command, they were kept intle. I call it, but it is public news for them and others [3], but this is an adequate duty Transforms into the following rules of reference:

1. In-kind obligatory: This is if it does not exist in the Muslim community or if the time of the incident is narrowed or is afraid to miss it, it says in the book of the most wills: "The Refuse the boy if there is a world based in the country, otherwise he may not respond to her appointment. on it "[1].

2. Al-Nadad: Fatwas shall be a delegate if the Mufti is asked about issues Expected to happen, Mufti is not obliged to answer, because it does not exist at the time of need.

3. Prohibition: Fatwas may be haraam for some, and those They are those who do not meet the conditions of fatwas, or were not thoroughly aware of the matter in place of question.

4. Hating: Fatwas may be makrooh, like someone who asks for questions of Impossible to fall. He hates the Mufti to keep up with him for what it costs.

5. Permits: Fatwas is permissible except in cases. The previous four [2].

Several texts were received from the Qur'aan and Sunnah showing the status of Al-Aqsa Mosqueand its virtues. In this requirement, the researcher shall monitor some of these texts as follows:

First: The Virtues of Al-Aqsa Mosque in the Holy Quran

The Al-Aqsa Mosque in the Holy Qur'an is expressly mentioned in its name, or with reference to

The pond of his land and its surroundings, the verses were as follows:

The face of the connotation of it: In verse a statement of the virtue of the Al-Aqsa Mosque in Israa the Messenger e, and his arrogance to heaven from it, The wisdom of God Almighty required that limping the prophet e of Al-Aqsa Mosque to show this important link between the sanctuaries Islamic, and this symbolic for Muslims that they have to protect Al-Aqsa Mosque as They protect the Grand Mosque, SayedQutb says: "The journey from the Grand Mosque to Al-Aqsa Mosque A Selected Journey from LatifAlkhabir, linking the doctrines of major unification by Ibrahim and Ismael peace be upon them, to Muhammad the ring of the prophet e, connecting the holy places of religions All unification. It's like I want this great journey to proclaim the last Apostle's inheritance to sanctuary. The apostles before him, the inclusion of these sanctuaries, and the link of his message to them all. It's a trip symbolizes beyond the boundaries of time and space; encompasses wider horizons and horizons of time and space; It includes greater meanings than close meanings that unfold at first glance. The description of the mosque Al-Aqsa is a description that draws the blessing to the edge of the mosque, surplus to it. Which is a shadow He wouldn't have given him a direct expression like: bless him. Or bless us in it. That is one of the minutes of the Quranic expression Wonder "[1].

\section{2. (AlmightySays:) $O$ Get into the holy earth, which God has written to you, and do not turn} back. To your reins and turn down losing (. (Ma'idah: 21)

The face of the indication: that Moses (peace be upon him) ordered his people to enter the Holy Land the Holy House and around it, and in this sign that this spot of the earth is a blessed antiseptic. 


\section{Second: The Virtues of Al-Aqsa Mosque in the Sunnah}

There have been many hadeeth showing the virtue of the Al-Aqsa Mosque, including these. The hadeeth include:

1. About Abi Said Al Khudri t It was happening with four about the Prophet e so I liked me and I cossed me, he said: "A woman shall not fly two days, except with her spousal or who is haram, And not to fasten in the days of the fater and the adhahy, but there is no prayer after two prayer: After the morning until the revelation of the solace, and after the time until it goes down, And the Travellers shall not be screwed only to 3 mosques: the mosque of the haram, and a mosque. The most, and my mosque" [1].

1. About dad kitten t Informs the Prophet e: "Thou shalt not pull the Travelers but to the Three Mosques of this mosque and a mosque. The haram and the mosque of the al-Qas' '[1].

The significance of them is that both hadeeth indicate that he does not mean a mosque to travel to it. He requested only these three mosques mentioned, and in this statement of their virtue, in which he says Al-Nawawi explained in Saheeh Muslim: "A great statement is the virtue of these three mosques and their because they are mosques of the prophets, the prayers and peace of Allah upon them and the virtue of praying in them" [2].

1. About Abi Dhar t He said: I said, O Messenger of Allah: Which mosque was placed in the ground first?, He said: "The mosque of haram", I said, "Then any?" He said: "The mosque of the most qas"', I said, "How many were between them?, He said: "forty years, and then whichever prayerth thou grasp after he prayerth him. For the good is in him" [1].

The face of the connotation: the Al-Aqsa Mosque has the primacy of its construction, since it is clearly From the text of the hadeeth, it is the second mosque placed for the people, and it was rebuilt by Solomon (peace be upon to worship since the past.

2. ABDULLAH BEN AMR T About the Prophet e He said: "When Saliman the ibn of Dawud had left the building of the house of the saints. God asked 3: A judgment that will happen to his judgment, and a king that shall not be absent to anyone After him, and that this mosque should come no one who wants nothing but prayer. In him, but he went out of his sins as the day his mother was born. The prophet said e either Two have been given to them, and I hope that they may have been given the third" [2].

The face of the connotation: In the hadith of the Prophet e that who went out to the Al-Aqsa Mosque He wants to pray in him except that Allaah forgives him. This is a virtue for him, since the one who prays in him forgives his sins.

1. About Umm Salamah About her she said: I heard the Messenger of Allah e say: "Who is the people of the mosque of the most holy In 'Umrah or under the prey of God's forgiveness for him, what he has come from his sin" [1].

The indication is that there is a statement of the virtue of ihraam from him for Hajj or 'Umrah, and this is in it He urged Muslims to make the building of the Al-Aqsa Mosque, and did all other worship in it.

2. about Dad ther t He said: Our tickets when the Messenger of Allah e Emma better: Mosque Messenger of Allah e, Or the mosque of Jerusalem? Messenger of Allah e said: "Prayer in my mosque better than four prayers in it, And for yes the worshippers, and for Lushkin to have a man like his bow from the earth, where the holy house shall see good. to him from the world and what it is." [2]

3. About AbiDardaa t About the Prophet e He said: "The virtue of praying in the Grand Mosque over others is one hundred thousand prayers, and in two mosques one thousand prayers, There are five hundred prayers in the Beit al-Maqdis Mosque" [3].

The connotation of them is that there is a statement of the virtue of prayer in the Al-Aqsa Mosque. and doubling the reward for those who prayed in it, in this he urged Muslims to seek prayer and revive it. Worship.

4. ABDULLAH BENUR May Allah be pleased with them said: I heard the Messenger of Allah e say: "It is the migration after the migration, the choice of The people of the earth committed them to the immigrant of Abraham, and there remain in the land the evil of its people, and they shall utter them their land, and they shall tarnise them. The Same of God, the fire of them with monkeys and pigs" [4]. 
The face of the connotation: that the prophet e wishes Muslims to migrate to Sham and Rabat in it, and this shows its virtue over the rest of the country, and perhaps its virtue was of blessing Al-Aqsa Mosque.

\section{CONCLUSiON}

From the above Quranic and prophetic texts, it turns out that Islamic law has given rise to Al-Aqsa Mosque has a great place, and it has made many virtues, and Muslims would like to pray in it and seek it, perhaps an indication that this mosque must remain in the hands of Muslims To be able to perform worship in it, and that they must protect it and sacrifice for it and jihad. in order to free him from angry people.

\section{Third: Fataawa al-Masjid al-Aqsa Fataawa}

It is known that the Al-Aqsa Mosque has a great place among Muslims; it is the first Qiblatain, the second mosques, Masra Messenger of Allah e, the reward of prayer in it doubling, the hearts of Muslims nostalh to him, and in which prayer Before the death. Located these days under Zionist occupation, a usurper left, seeking to lullaby him. and the establishment of the alleged temple on its rustles, in such circumstances anyone who wanted to pray in the mosque Al-Aqsa from nonPalestinians needs a visa authorizing him to enter from the occupier, disagreed The scholars are in the ruling on praying in it on an Israeli visa from non-Palestinians.

The scholars agreed that it is obligatory to pray in the Al-Aqsa Mosque, which is free and loose. Muslims, and they supervise it, but they differed in the passport of visiting him on a visa from the occupier to not Palestinians have two opinions:

The first opinion: He authorized his visit with the permission of the occupier, and he chose this The opinion is a number of scholars most notably Ali Juma, and Habib Ali Jafri who visited him [1].

Second opinion: He said the sanctity of his visit with the permission of the occupier, and chose This opinion gathered a large number of scholars including Yusuf al-Qaradawi [2], and Hussam al-Din Pustiness [3], the research complex Islamic Islamic in Al-Azhar [4].

Both teams have obtained evidence, which we set out as follows:

\section{Evidence:}

\section{First: Opinion Evidence The first}

Incert who authorized the visit of Al-Aqsa Mosque on a visa from the occupier with a number of evidence as follows:

1. About Abu Kitten T reports about the Prophet e: "Do not overdo the Travellor only to the 3 mosques of this mosque and the mosque of the haraam and the mosque of the Aqsa" [5], and from Abu Dardaa t from the prophet e said: "The virtue of praying in the mosque One hundred thousand prayers, one thousand prayers in two mosques and one thousand prayers in Beit al-Maqdis mosque, five hundred prayers" [6].

Face of inference Of them: that the Prophet e wanted to visit Al-Aqsa Mosque He tighten the backpacker to him, and between his virtue over other mosques, and the hadeeth mentioned in this The field did not differentiate between his visit if he falls under occupation or otherwise, and since it is not permissible The transition from the rule of origin to another rule except the presence of a stronger opponent than him, it remains the sentence on Its origin is the passport to visit Al-Aqsa Mosque anyway [7].

Object to it: the most implied by these texts is It is not obligatory to visit Al-Aqsa Mosque, but it is necessary to visit him in case of the presence of the occupier with permission A statement from him is an explicit recognition of his right to him, and this is a more corrupt than the desired interest. than his visit in this situation. Moreover, Islamic law requires us to work to liberate any A spot of Muslim land if it falls under occupation, how if the occupied part is the mosque the maximum?

In return, the Sharia did not order us to confess to the enemy and accept permission from him. to visit. Then whoever wants to earn more wages will lead the backpacker to the Grand Mosque or the Mosque the Prophet's Prophet, the reward for praying in them is greater than in Al-Aqsa Mosque. 
1. Prayer of the Prophet e in Al-Aqsa Mosque on Journey Al-Israa and Al-Mi'raj, who was then under the occupation of the Romans, if it were forbidden for what he did. The Messenger of Allah e He is an example in it [1].

Object to it: that this is an inferred Strange, should he ask the permission of the Messenger of Allah e from the Roman to visit the Al-Aqsa?! And did the Romans know about the Messenger of Allah e from this visit?!

The Israa case And al-Miraj is a miracle supernatural, honored God Almighty by his Prophet e, and it is not correct to measure them.

2. That the Prophet e visited Mecca in the judiciary 'Umrah Under Quraish and its sovereignty, they have obtained the approval and permission of the infidels, was the prophet e satisfied with the occupation of the infidel enemy To Mecca in such a case? [2].

Objection: that the Prophet e for what visited Mecca in the judiciary 'Umrah The visit was a breakthrough in the political and moral system, and public prestige. Gurish among the tribes, as it reveals a major concession from Quraysh in favor of Muslims, As a result of Quraish's feeling of shifting the balance of power; therefore, the political interest and appreciation The prophet's strategic direction towards entering Mecca is under the sovereignty of KfarQuraish.

The estimate political to visit Al-Aqsa Mosque as it is present represents a great service to the occupant, it suffers from Political isolation, a global feeling that he is a usurper of Jerusalem and a criminal against the Palestinians, He breaks from him this isolation and shows his sovereignty over this land through such visits.

3. Visit under The occupation done by senior scholars in the days of the Crusade occupation of Jerusalem, such as these imam. Al-Ghazali and Abu Muzaffar al-Samaani, al-Subaki said in the layers of Shaafa'i: "He went out to Hajj. In Dhu al-Qa'dah, eighty years, and his brother was taught. He entered Damascus in nine years. and eight, with easy diaries, on the foothold of poverty. Then he went to Jerusalem and went to it. Duration. Then he returned to Damascus, and Itiqaf at the western lighthouse of the mosque, and there was his residence" [1]. And in the gold nuggets The text came: "And he went out to the Hejaz in the year of eighty eight, and then went back to Damascus and settled it. Ten years at the lighthouse of the mosque and classified books where the revival is said to be from which then came to Jerusalem and Alexandria" [2]. It is known that the occupation of Jerusalem was the year $492 \mathrm{AH}$. If we count the ten years after the year of Hajj, he will visit Jerusalem. At the earliest in $498 \mathrm{AH}$, which is definitely after the occupation. As the golden transfer that Abba Muzaffar Al-Samaani visited Jerusalem under occupation, Al-Dhahabi said: "He visited Jerusalem and Hebron In the hands of the frang, you refer and risk in that, and what is prepared for the Salafi or the son of Asaker" [3].

Object to it: that what they mentioned of Imam Ghazali's visit to the city of Jerusalem during the occupation time is a shame saying about health. Ibn al-Atheer in full history clearly that Ghazali visited Jerusalem in 488 A.H. It read in this year's incidents: "In which Imam Abu Hamid al-Ghazali went to Sham and visited Jerusalem, leaving teaching in the regular, grasping his brother, asceticism and coarse wear" [4]. Which corresponds to what Al-Ghazali himself said about his trip to Jerusalem in his book Savior from Astray, where he said: "So Baghdad left, I dispersed what I had with me, and I saved only the amount of subsistence, and I saved the children. Then I entered the Sham, and I did it soon for two years. I worked my job except solitude and solitude. I was I'tiqaf. For a while in Damascus Mosque, I went up the mosque lighthouse all day long, and I closed her door on myself, and then I left her. To the Holy House, I enter every day the rock, and I close her door to myself. Then I moved in an immense advocate. Pilgrimage, deriving from the blessings of Mecca and Medina and visiting the Messenger of Allah e after the completion of the visit to Hebron God's prayers and peace be upon him, I was interpreted to the Hejaz, then I was drawn by determination, and the children's calls back home, and I returned after I was far away. Creation from returning to it, and also opted for isolation in order to be alone, and liquidate the heart of the male. The accidents of time, the missions of the Eyal, and the necessary living, changed the face of the desired, and the confusion of the elite Being alone, I was only described in the sporadic forces. But I do not, however, cut off my food from her, So it pushes me from her obstacles, and I return to her. It lasted ten years." [5] So the Their argument that Imam Ghazali had visited Jerusalem at the time of occupation had fallen. 
Abu Muzaffar's visit It is clear from the context of what Althahabi said that it is an unfamiliar work of his time, and that Abba Muzaffar He used a ploy, risked to enter Jerusalem, and did not ask the occupiers for that.

4. that prevent a visit Al-Aqsa Mosque at the time of the occupation, such as the sent interests that the scholars did not agree on Its authority [1], says IbnQudaamah In Rawdat al-Nazer: "Malik and some Shaafa'is are of the view that this interest is an argument... And the correct that that is not an argument" [2].

Object to him: that Islamic law was based on bringing interests and pushing for irreversible The takeholders, if the thing overcomes the corrupt side of the interest; judged intact in order to pay damage expected. Visiting Al-Aqsa Mosque under the occupation has the interest of collecting wages and reward. and in which the normalization and recognition of the occupier and its legitimacy on the territories under its control are corrupt, Indeed, the situation between Muslims and occupiers is a state of war, it is unacceptable to turn into a state of peace without turning back from their occupation. They have been turning a blind eye to the daily Judaization to which the Al-Aqsa Mosque and Jerusalem are exposed, and the displacement to which its inhabitants are subjected. That's corrupt. I overcome the interest of collecting wages and reward, where the corrupt side prevails over the interest, and thus become a considered interest.

5. that on a visit to Jerusalem Support for the steadfastness of its people before the occupiers, and the lack of worshipers and ages for Al-Aqsa Mosque leads to His abandonment, which in turn weakens the connection of the nation and its generations to this house, and this strengthens the The occupier in isolating Al-Aqsa from the Muslims and demolizing him.

Object to him: a visit that will take no more than two days will not increase the steadfastness of Jerusalemites much, but It serves the occupier even more by strengthening its legitimacy. There are also over a quarter of a million Palestinians visit Al-Aqsa Mosque and pray in it, and if they want to strengthen resilience Al-Aqsa Mosque support it with money and raise its cause in international forums and the media. Let them teach their children their civilization and introduce them to their sanctities, so that future generations do not forget Al-Aqsa Mosque, and I don't think that will happen, and Muslims recount Surat Al-Israa, and remember among them Miracle of Israa and Mi'raj

Based on the above, the texts they invoked do not produce significant evidence To indicate the passport of visiting Al-Aqsa with the permission of the occupier.

\section{Second: Evidence of Second Opinion}

The second opinion holders inquerted from those who say the sanctity of visiting Al-Aqsa Mosque on a visa of the occupier by a number of evidence as follows:

1. To visit the mosque Maximum desirable year, fight the enemy with all possible tools and duty, it is known It is stated that the duty is submitted to the mustahabb.

2. Othman Bin Affan Position t in Al Hudaybiyah where the Mushakeen authorized him to do tawaaf in the Ka'bah before the reconciliation took place, and he refused to do so. Came in the biography of the son Hisham: "Osman went up until Abba Sufyan and greats Quraish, inform them about the Messenger of Allah e to them: If you want to float At home, he said: I would not do so that the Messenger of Allah (e) [1]. Fathman t refused to do tawaaf at home even though He was in his sight, because of serious political dimensions, it was his company.

3. that it has to If Muslims occupy an inch of their land, they can liberate it with all the power they have come, how This ravaged land was the land of al-Isra' and al-Mi'raj, which increases the task, They could not fight him like they were in these days. They had to fight him with all the tools. available to them from economic, social, political or other boycott, not to normalization with the occupier and recognition of its legitimacy [2].

4. To treat Muslims With the enemies of God, Almighty, and with those who occupy their land by selling, buying, tourism and travel and others that tightens the occupier's Azar, and strengthens their economy, which works to perpetuate the aggression against the Muslims are making material gains as a result of our dealings with them, and this is a kind of cooperation on sin and aggression against Muslims [3], which is haraam in the text of the Qur'an Karim:) And they worked on righteousness 
and strength, and do not work together for iniquity and affliction; God, God has tighten the punishment (Ma'adah: 2).

5. That during the visit to Al-Aqsa Mosque with the permission of the occupation in recognition of his right to Jerusalem, which the occupier wishes behind this visit.

6. Thousands of Muslims People of Palestine, people living in close proximity to Al-Aqsa Mosque are deprived of visiting and praying why would the occupier authorize those who come from outside Palestine and deprive his neighbors of it?!

\section{Weighting:}

After presenting the evidence of the two teams in the ruling on visiting Al-Aqsa Mosque on a visa from the occupier, The researcher believes that the second opinion is more likely, for the strength of their evidence and the validity of their point of view; and because the issue does not seen in abstract texts, it is necessary to study the interests and the corruptions of order, holding a balancing between them, the spoiled will overcome the interest, as in this matter, presented the side of the spoiled fend on the side of bringing interest.

\section{Conclusion}

Thank God that With His Grace, righteousness shall be done, and peace and blessings be upon Muhammad Khair al-Barat, and upon his family and companions and those Followed by, after,

And after that of God the researcher should study this topic, he concluded a number of conclusions and recommendations, registered for the sake of full interest.

\section{First: Results}

1. That the question of visiting Aqsa mosque on a visa from the occupier coming down contemporary jurisprudence needs an impartial study on whims.

2. To visit the mosque the maximum is mustahabb, and normalization with the enemy is haraam.

3. To say that visiting Al-Aqsa Mosque on a visa from the occupier is haraam, more likely than others.

\section{Second: Recommendations}

After the results that recorded by the researcher through this study, it recommends a sentence of recommendations, as Next:

1. This should be studied matter of specialized scientists, not media professionals or others.

2. When studying the subject of the view of Islamic jurisprudence, should be stripted from political affiliations and personal whims.

3. Work to support resilience Al-Aqsa Mosque collects donations for him, raising its theme at the regional and international level, and strive to free him from the hands of the raped enemy.

That's what's been restricted. Between the two sides of this search, what was right in it is with good luck and help from Allaah, and what was From mistake or forgetting it is myself and from Satan, God and His Messenger are innocent, and I ask Allah that It makes it pure to his honorable face, useful to me on the day of religion, a day that does not benefit money and no sons except from God came with a healthy heart.

And the last we let that Praise be to Allaah, the Lord of the Worlds and peace be upon our Prophet Muhammad and his family and companions.

\section{SOURCES AND REFERENCES}

First: The Holy Qur'an.

Second: Arabic References

[1] Ibn Al-Atheer, Ali Bin Mohammed Al Shaibani Complete in history, investigation: Mohammed Yusuf Dakkak, Scientific Books House, Beirut, i 1, 1407 AH/1987.

[2] Ibn al-Bazaz Muhammad ibn Muhammad ibn Shihab al-KurdiHanafiFataawa al-BazaziyahPrinted in the margins of Indian Fatwas from Part 4 and Beyond, House of Revival of Arab Heritage, Beirut, $1406 \mathrm{AH}$ /1986, i 4. 
[3] Ibn al-Imad, Imam ShihabuddinAbi al-Falah 'Abd al-Hay ibn Ahmad bin Muhammad al-Ekri Gold nuggets in the news of gold, investigation: Abdul Qader Al-Arnaout Mahmoud Arnaout, Dar revival IbnKatheer, Beirut, i 1, 1406AH/1986 AD.

[4] IbnHanbal, Ahmad. Misnad, investigation: Shuaib Al Arnaout and Adel Murshid, Resala Foundation, Beirut, i 1, $1416 \mathrm{AH} / 1995$.

[5] Ibn Zakaria, Abu Hassan Ben Fares. Glossary of Language Metrics, Investigation: Abdul Salam Haroun, Dar Al-Jeel, Beirut, $1411 \mathrm{H}$, i 1.

[6] IbnAbdeen, Muhammad bin Amin Omar. Footnote of the response of the Muhtaar to the chosen dor in Explanation of Enlightenment Al Absar, Dar Al Marefa, Beirut, i 2.

[7] IbnQudaamah, Muwaffaq Religion Abdullah bin Ahmad al-Maqdisi Kindergarten of the Nazer and the Garden of the Views, Scientific Books House, Beirut, i 2, 141414AH/1994 AD.

[8] IbnQim al-Jawziyah, Shams al-Din Abu Abdullah Muhammad ibn Abi Bakr. Informing the signatories about the Lord of the Worlds, Press New Renaissance, Cairo, 1388 AH /1968 AD, dt.

[9] IbnMajah, Mohammed Bin Increases Qazwini. SunanIbnMajah, investigation: Mohammed Nasser Religion Albaani, took care of him: Mashhour bin Hassan Al Salman, Maaref Library, Riyadh, i 1.

[10] IbnManzour, Abu Al-Fadl, Gamal al-Din Mohammed bin Makram, African-Egyptian. Arabic tongue, Dar Sader, Beirut, 1374 AH/1955 AD, dt.

[11] Son of Nizam al-Din, Abd al-Ali Muhammad al-Ansari. FawatahRahmawt explained Muslim Al Thabit, the princes printing press in Boulak, Egypt, $1322 \mathrm{H}$, dt. It is printed in the margins of the hospital For Ghazali.

[12] Ibn Hisham, Abed King bin Ayoub al-Hamiri al-Basri. Biography of the Prophet, Arab Book House, Beirut, i 3, 1410 AH/1990.

[13] Al-Amdi, Saif al-Din Ali bin Mohammed Enforcement of the Assets of Judgments, Egypt, dt.

[14] Bukhari, Mohammed Bin Ismail. Right Mosque, Achievement: Moheb al-Din al-Khatib, Press Salafi, Cairo, 1400 AH, i 1.

[15] Al Bahuti, Mansour Bin Younis Ben IdrisMontaha Al-Edraat, Dar Al-Fikr, Beirut, Dr. Di.

[16] Al Bayhaqi, Ahmed Bin Al Hussein. The Whole for the People of Faith, Achieve: MukhtarNadwa, AlRashd Library, Beirut, i 1, 1423H, 2003

[17] Al Bayhaqi, Ahmed Bin Al Hussein. The Whole for the People of Faith, Achieve: MukhtarNadwa, AlRashd Library, Beirut, i 1, 1423H, 2003

[18] Al Jarjani, Ali Bin Mohammed bin Ali Definitions, investigation: Ibrahim Al-Abyari, Dar Arabic Book, Beirut, $1405 \mathrm{AH}$.

[19] Governor of Neisaburi, Al-Mudarak Ali Al-Saheeheen, Dar Al-Marefa Beirut, i 1.

[20] Hassan, Hussein Hamed. Introduction to the study of Islamic jurisprudence, Dar Al-Nahda Arab, Cairo, $1972 \mathrm{~m}, \mathrm{i} 1$.

[21] Al-Hanbali, Ahmed Bin Hamdan Al-Harani. Fatwa and Mufti The mufteta, investigation: Mohammed Nasser Albani Religion, Scientific Books House, Beirut, 1404 H, 4th.

[22] Golden ‘Shams El Din Mohammed bin Ahmed bin Othman. The progress of the flags of the nobility, investigation: Shuaib Al-Arnaout and Mohammed Al-Arqsousi, Foundation Resalah, Beirut, i 1, 1405 AH/1985

[23] Razi, Muhammad ibnAbiBakrMokhtar Al Sahah, library Lebanon, Beirut, 1993, D.C.

[24] Zuhaily, a gift. A brief interpretation on the sidelines of the Great Qur'an With the reasons for descent and rules of the motel, Dar al-Fikr, Beirut, 1415 AH/1994, i 1.

[25] Al Sabki, Taj Al Din Abi Nasr 'Abd al-Wahab ibn 'Ali. Grand Shafi'i layers, investigation: Abdel Fattah El-Helu and Mahmoud Al-Tnaji, Dar Revival Arabic Books, Beirut, d. i.

[26] Samaani ،Abu Al Muzaffar Mansour bin Mohammed Evidence cutters in the origins of jurisprudence, investigation: Abdullah al-Hakami Library Al Tawbah, Riyadh, 1419 AH, i 1.

[27] Shaltout, Mahmoud. Fatawa, A Study of the Problems of Contemporary Muslim In his daily and public life, Dar El Shorouq Press, Cairo, 1421 AH/2001, i.

[28] Tabarani ،Suleiman Ben Ahmed. Middle Dictionary, investigation: Tariq bin Awadallah bin Muharram Abdul Mohsen Husseini, Dar Al Haramain, Cairo, i 1, 1415 AH/1995.

[29] Al-Ghazali, Abu Hamed Mohammed bin Mohammed. Infirstary of Assets, investigation: Hamza bin Zuhair Hafez, Medina, i 1.

[30] Ghazali ‘Hajjah Islam Abu Hamid. Savior from the astray, investigation: SaadKarim El Feki, Dar IbnKhaldoun, Alexandria, Dr. 
[31] AlFayrouzabadi, Mohammed Ben Jacob. Ocean Dictionary, Message Foundation, Beirut, 1419 AH, i 6.

[32] dimacrificial, Shahabuddin Ahmed ibn Idris tightening In the Distinction of Fatwas on the Rules, Islamic Publications Library, Aleppo, 1416 AH, i 2.

[33] Al-Qarrafi, ShehabEddin Ahmed ibnIdris Al-Thakhira, Investigating Mohammed Abu Khbaza, Dar AlGharb Islamic, Beirut, 1944 AD, i 1.

[34] Al-Qarrafi, ShehabEddin Ahmed ibn Idris Anwar Al Barouq at Anwaa Al Fariq, Dar Al Marefa Printing, Lebanon, D.C.

[35] Qaradawi, Yusuf Who threatened Islam: FataawaMa'asra, Dar al-Qalam Cairo, i 3.

[36] Qaradawi, Yusuf From the Hoda of Islam: FataawaMa'asra, Dar al-Qalam Cairo, i 3

[37] Al-Qurtubi, Abu Abdullah Muhammad bin Ahmed bin AbiBakr. Compilation of the provisions of the Qur'an and clarifying what it contains from the Sunnah and Ay al-Furqan, edited by: Abdullah bin AbdulMohsen al-Turki, The Resala Foundation, Beirut, 1427 AH / 2006 CE, ed. 1.

[38] Qutb, mister. In the Shadows of the Qur'an, Dar Al-Shorouk, Cairo, 1423 AH / 2003 CE, 32 ed.

[39] Muslim Ibn Al-Hajjaj Al-Qushayri Al-Nisaburi, Al-Jami Al-Sahih, Dar Al-Mughni, Riyadh, 1419 AH, 1st floor.

[40] Al-Nawawi, Abu ZakariaYahya bin Sharaf Al-Dimashqi. Sahih Muslim, Sharh Al-Nawawi, The Egyptian Press, Cairo, 1347 AH / 1929AD, Edition 1.

[41] Al-Nawawi, Abu ZakariaYahya bin Sharaf Al-Dimashqi, Al-Majmoo 'Sharh Al-Muhdhab, Dar Al-Fikr for Printing and Publishing, Beirut, d.

[42] Al-Nawawi, Abu ZakariaYahya Bin Sharaf Al-Dimashqi, Kindergarten of the Talibin, edited by: Adel Abdul-Mawgid and Ali Moawad, Dar Al-Kutub Al-Ulmiyyah, Beirut, 1412 AH, ed. 1.

\section{AUTHORS' BIOGRAPHY}

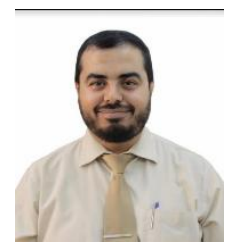

Name: Muhammad Hassan Ali Alloush, Date of birth: 05/05/1983 AD, Nationality: Palestinian Gender: Male, Marital status: Married, Current academic degree: Professor - Assistant Professor - Associate Professor - Teacher - Researcher.

The institution in which you are currently working (university, institute): Al-Aqsa University) Country: Palestine College / Administration / Scientific Department / Division: Al-Aqsa Community College. General specialty: Jurisprudence and its fundamentals Subspecialty: Fundamentals of Fiqh PhD thesis title (in Arabic): Preventive Sharia measures to curb new financial crimes. University that issued the certificate: The International Islamic University. Year: 2012 Country: 0 Malaysia

$\mathrm{PhD}$ thesis language: Arabic

The title of the MA thesis (in Arabic): The license of the fundamentalists and its relationship to the ranks of the objectives of Sharia)

University that issued the certificate: The Islamic University Year: 2009

Country: 0 Palestine

The language of the master's thesis: Arabic Proficiency level of Arabic languages: Excellent (mother tongue) English: Good: Research interests (list 5 topics)

(1): Fundamentals of jurisprudence and rules of jurisprudence

(2): Contemporary Financial Transactions

(3): Cybercrime

(4): Penalties

(5): Sharia policy

Citation: D. Mohammed Hassan Alloush. "Fataawa Al-Masjid Al-Aqsa on a Visa From Occupier (Critical Study)" International Journal of History and Cultural Studies (IJHCS). vol 6, no. 3, 2020, pp. 1-12. doi: DOI: https://doi.org/ 10.20431/2454-7654.0604001.

Copyright: () 2020 Authors. This is an open-access article distributed under the terms of the Creative Commons Attribution License, which permits unrestricted use, distribution, and reproduction in any medium, provided the original author and source are credited. 